
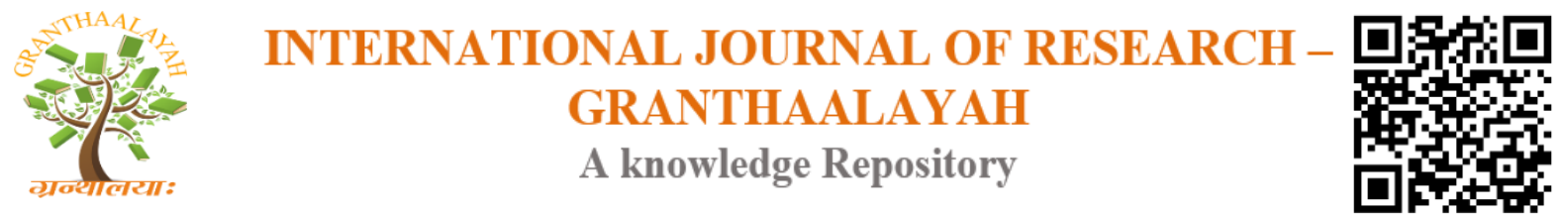

Science

\title{
CONCEPTUAL STUDY OF ANTI-TOXIC ACTION OF TAGARADI AGADA ON POISONOUS INSECTS BITE: A SHORT REVIEW
}

\author{
Dr. Shruti Dinesh Bhokare *1, Dr.Sandip Kondibhau Jadhav ${ }^{2}$ \\ ${ }^{* 1}$ HOD and Professor, Department of Agadtantra, L.R.P. Ayuvedic Medical College, Research \\ Center and P.G. Institute, Islampur, Sangali, Maharashtra - 415409, India \\ ${ }^{2}$ M. D. Scholar, Agadtantra Department, L.R.P. Ayuvedic Medical College, Research Center \\ and P.G. Institute, Islampur, Sangali, Maharashtra - 415409, India
}

\begin{abstract}
Rapid urbanization lead to frequents encounters with wild animals and insects which leads to health hazards. Poisoning due to insect bite may warrant immediate medical attention. Tagaradi Agada is one of such agada useful in poisonous insect bite which is mentioned in ashtang sangraha uttartantra vishapratishedha adhyaya. Shloka phalashruti has mentioned its specific anti-toxic effect in makshika visha. This review is for collective information of therapeutic and pharmacological study of this agada for makshika visha poisoning.

Keywords: Tagradi Agada; Makshika Visha; Agada.

Cite This Article: Dr. Shruti Dinesh Bhokare, and Dr. Sandip Kondibhau Jadhav. (2020). "CONCEPTUAL STUDY OF ANTI-TOXIC ACTION OF TAGARADI AGADA ON POISONOUS INSECTS BITE: A SHORT REVIEW." International Journal of Research Granthaalayah, 8(4), 99-103. https://doi.org/10.29121/granthaalayah.v8.i4.2020.13.
\end{abstract}

\section{Introduction}

Agada-Tantra is the branch of Ayurveda which deals with various kind of poisons broadly classified as Sthavara visha (poisons which have plant origin and mineral origin) and Jangam Visha (poisons which have animal origins). it also describes various parts of it which leads to poisoning by each of them called as Visha Adhishthana. ${ }^{1}$ poisoning due to insect bite is one of the type of Jangam Visha poisoning. Makshika Visha (honeybee sting) is one of them. encounter with honeybees is now frequent as due to deforestation they have lost most of their habitat and now it is very common to see them making their nest on buildings.

Tagaradi Agada is one of the Agada Kalpa mentioned in Asthanga Sangraha Uttarsthana Vishapratishedha Adhyaya ${ }^{2}$. it is describing as Makshika Visha Nashanam. it has 4 herbal contents- Tagara, Sunthi, Nagakesara and Maricha 
Aim:

To study antitoxic action of Tagaradi Agada

\section{Objectives}

1) To study therapeutic and pharmacological action of each ingredient of Tagaradi Agada

2) To study pharmacological and anti-toxic action of Tagaradi Agada

\section{Materials and Method}

The whole study based on literary review collected from Ayurveda Sanhita Method of preparation of Tagaradi Agada

All ingredients are taken in same quantity and mixed well.

\subsection{Tagara}

Latin Name: Valeriana wallichii DC

Family: Valerianaceae

Chemical Constituent: Valerenic Acid, Valepotriates

Pharmacological Action: ${ }^{3}$ Coronary Dilating and antiarrhythmic effect, Anxiolytic activity, Sedative/Anticonvulsant Activity, gastrointestinal activity

Pharmacological action according to ayurveda: ${ }^{4}$

Tagara has Madhura Rasa, Ushna Veerya, Madhura vipaka, Snigdha and laghu guna. It has properties like Vishaghna, Shoolaghna,tridosha-shamaka

Therapeutic action: Akshirog nashaka, Apasmar nashaka

\subsection{Nagara}

Latin Name: Zingiber officinale Roscoe

Family: Zingiberaceae

Chemical Constituent: Zingeron, gingerdiol, zingibrene, gingerols and shogaols

Pharmacological Action: ${ }^{5}$ Antioxidant, Antiemetic, Anti-inflamatory, Analgesic, Cardioprotective, Anticlotting, Antibacterial,Antiviral, Antifungal Antiparasitic

\section{Pharmacological action according to ayurveda: ${ }^{6}$}

Shunthi has Katu Rasa, Ushna Veerya, Madhura vipaka, Laghu and snigdha Guna. It has properties like Ruchikara, pachaka, vrishya, swarya, shoolaghna, vamighna, Kapha-Vata shamaka

Therapeutic action: Aamvataghni, Shwasahara, Kasahara,hridrog, shlipada, shotha, arsha,

\subsection{Nagakesara}

Latin Name: Mesua ferrea Linn. 
Family: Guttiferae

Chemical Constituent: Coumarins, xanthones,terpenoids, and sterol type of phytochemicals, mesuol, mesuogin

\section{Pharmacological Action: ${ }^{7}$}

Antioxidant activity, Analgesic activity, Anti-inflammatory action, Anti-venom Activity, Diuretic properties, wound healing activity, Anticonvulsant activity/CNS depressant activity, Immunomodulatory activity.

\section{Pharmacological action according to ayurveda: ${ }^{8}$}

Nagakesara has Kashaya, tikta rasa, ushna veerya, Katu vipaka, laghu and ruksha guna. It has properties like Aampachaka, Kanduhara,trishanashaka,swedanashaka, chhardi-hrillasnashaka, vishaghna,Kapha-Pitta shamaka

Therapeutic action: Kushtha, Visarpa, jwara

\subsection{Maricha}

Latin Name: Piper nigrum, Linn

Family: Piperaceae

Chemical Constituent: Piperine, piperamine, piperamide, sarmantosine, sarmentine, trichosta Pharmacological Action: ${ }^{9}$ Anti-asthamatic activity, Antioxidant activity, Anti-inflammatory activity, Immunomodulatory activity, Anticonvulsant activity, Analgesic activity

\section{Pharmacological action according to ayurveda: $\mathbf{1 0}^{10}$}

Maricha has Katu Rasa, Ushna veerya, Katu Veepaka, Laghu and tikshna Guna, It has properties like Deepana, shoolahara, Kapha-vata shamaka

Therapeutic action: swasahara, krimihara

\section{Poisonous Insects: (Makshika Visha) ${ }^{11}$}

The well-known members of the Hymenoptera order are bees, wasps, hornets, yellow jackets and ants. This order in fact consists of about 100,000 species of bees, wasps and ants.

Many of these animals have poison glands and stinging apparatus. Two distinct families exist, the Apidae and the Vespidae. The genus Apis contains only the honeybee, while the genus Polistes and the genus Vespula contain wasp, yellow jacket and hornet.

Among the species of Hymenoptera, bees are the most commonly encountered species because of beekeeping activities. Two of the more commonly encountered species of bee are honeybee Apis mellifera and the bumblebee (Bombus species).

The non-allergic local reaction is a toxic response to venom constituents, while the large local reaction appears to be caused by an allergic reaction to venom proteins.

The IgE mediated late-phase reaction is probably responsible for most of these reactions; however, a Cell-mediated mechanism, or a combination of the two, is possible 
Clinical Features: Hymenoptera sting envenomation results in a number of clinical presentations (i) Non-allergic, local reactions (pain, minor edema, redness at the sting site);

(ii) Allergic, large local reactions (extensive swelling $>10 \mathrm{~cm}$ persisting more than $24 \mathrm{hrs}$ );

(iii) Anaphylaxis (generalized urticaria, angioedema, bronchospasm, hypotension, cardiovascular collapse and loss of consciousness); (iv) Systemic toxic reactions (edema, vomiting, diarrhea, headache, seizures and altered sensorium); (v) Unusual reactions (cardiac ischemia, encephalomyelitis and cerebral infarctions)

\section{Discussion}

Tagaradi agada have 4 herbal ingredients. These drugs contain many pharmacological properties like anti-inflammatory, anti-analgesic, anti-convulsant, cardioprotective, immunomodulatory activity, anti-asthmatic activities. Poisonous insect bite can cause non allergic local reactions like pain, minor edema, redness at sting site, also allergic reactions like extensive swelling and anaphylactic shock. Combined Pharmacological actions of Tagaradi Agada covers most of the symptoms due to poisonous insect bite which makes this agada preferred Agada in makshika visha

\section{Conclusion}

Ashtang sangraha mentioned Tagaradi Agada in vishapratishedha adhyaya specially for makshika visha treatment. This Agada can be used as local application as well as can be taken internally owing to its vishaghna, kandughna, shoolahara properties as well as its pharmacological properties like anti-inflammatory, anti-analgesic, anticonvulsant, cardioprotective, immunomodulatory activity, anti-asthmatic activities. The review of this article is to provide collective information on pharmacological and therapeutic use of Tagaradi Agada in makshika visha

\section{References}

[1] Vaidya Jadavji Trikamji Acharya, Narayan Ram Acharya, Susrutasamhita, seventh edition:2002, Chaukhamba Orientalia, Varanasi, page no.567

[2] Vaidya Anant damodar athawale, Ashtangsangraha, ayurvidyamudranalaya, page no.876

[3] Shahzad, Anwar \& Saeed, Taiba. (2015). A review on Phytochemistry, Pharmacological properties and Biotechnological studies in Valerianaofficinalis L., An important medicinal herb. Hippocratic Journal of Unani Medicine. 10. 53-71.

[4] Dr. G.S.Pandey, Dr.K.C.Chunekar, BhavaprakashNighantu, reprint 2002, choukhambabharati academy, Varanasi page no.199

[5] Wakchaure, Rajesh \&Ganguly, Subha. (2018). Phytochemistry and Pharmacological Properties of Ginger (Zingiberofficinale).

[6] Dr. G.S.Pandey, Dr.K.C.Chunekar, BhavaprakashNighantu, reprint 2002, choukhambabharati academy, Varanasi page no. 13

[7] Asif M, Jafari SF, Iqbal Z, Revadigar V, Oon CE, Majid ASA, Majid AMSA. Ethnobotanical and Phytopharmacological attributes of Mesua ferrea: A mini review. J App Pharm Sci, 2017; 7 (04): 242-251.

[8] Dr. G.S.Pandey, Dr.K.C.Chunekar, BhavaprakashNighantu, reprint 2002, choukhambabharati academy, Varanasi page no.230 
[9] Damanhouri, Zoheir\& Ahmad, Aftab. (2014). A Review on Therapeutic Potential of Piper nigrum L. (Black Pepper): The King of Spices. Medicinal \& Aromatic Plants. 3. 161. 10.4172/21670412.1000161.

[10] Dr. G.S.Pandey, Dr.K.C.Chunekar, BhavaprakashNighantu, reprint 2002, choukhambabharati academy, Varanasi page no. 17

[11] Rayamane, Anand \& P, kumar \& G, kishor \& R, Dayayanada \& Saraf, Ashish. (2014). HONEY BEE STINGS AND ANAPHYLAXIS: REVIEW. Journal of Forensic Medicine, Science and Law. 23.

\footnotetext{
*Corresponding author.

E-mail address: shrutibhokare@gmail.com
} 